\title{
Pemberdayaan Kaum Miskin Sebagai Panggilan Gereja terhadap Masalah Kemiskinan
}

\author{
Sharon Michelle 0. Pattiasina \\ Gereja Protestan Maluku, Ambon \\ michellepattiasina1013@gmail.com \\ D0I: https://doi.org/10.34307/ b.v4i1.238
}

\begin{abstract}
This article aims to analyze empowerment measures as a church calling on the poverty problems faced by the people. These problems cover various aspects of life, namely education, health, economy and infrastructure including transportation, housing and drinking water. This research uses qualitative methods with interview techniques, observation, documentation, and literature study.The results of the study found that the people of Siahari hamlet experienced poverty in absolute and relative terms. Therefore, in the task and calling of the church, GPM is called to empower people by referring to the theological foundation of Christian faith. In addition, the church can also build cooperation with the government so that empowerment actions can be carried out holistically and produce change for them.
\end{abstract}

Keywords: GPM, Poverty, Empowerment, Siahari.

Abstrak: Artikel ini bertujuan menganalisis tindakan pemberdayaan sebagai panggilan gereja terhadap masalah kemiskinan yang dihadapi oleh umat. Masalah tersebut mencakup berbagai aspek kehidupan, yakni pendidikan, kesehatan, ekonomi dan infrastruktur yang meliputi transportasi, perumahan, dan air minum. Penelitianini menggunakan metode kualitatif dengan teknik wawancara, observasi, dokumenasi, dan studi pustaka.Hasil penelitian menemukan bahwa masyarakat dusun Siahari mengalami kemiskinan secara absolut dan relatif.Oleh sebab itu, dalam tugas dan panggilan gereja maka GPM terpanggil untuk memberddayakan umat dengan mengacu pada landasan teologis iman Kristen. Selain itu, gereja juga dapat membangun kerja sama dengan pemerintah agar tindakan pemberdayaan dapat dilakukan secara holistik dan menghasilkan perubahan bagi mereka.

Kata kunci: GPM, Kemiskinan, Pemberdayaan, Siahari

$\begin{array}{llll}\text { Article History } & \text { Received: 24-02-2021 } & \text { Revised: 11-06-2021 } & \text { Accepted: 13-06-2021 }\end{array}$

\section{Pendahuluan}

Masalah tentang kemiskinan dalam kehidupan bergereja telah banyak diteliti oleh parapenulis terdahulu seperti yang dilakuan oleh Nugroho dan Nanuru. ${ }^{1}$ Akan tetapi,

1 Fibry Jati Nugroho, "Gereja dan Kemiskinan: Diskursus Peran Gereja di tengah Kemiskinan," EVANGELIKAL: Jurnal Teologi dan Pembinaan Warga Jemaat, 3. No. 1 (2019): 100-112; Richardo Nanuru, 
penelitian yang dilakukan lebih merujuk pada pandangan gereja terhadap masalah kemiskinan. Dalam penelaah hasil penelitian tersebut, penulis tidak menemukan aksi atau tindakan yang harus dilakukan oleh gereja sebagai sebuah panggilan untuk memberdayakan. Oleh sebab itu, tulisan ini berupaya untuk menggali lebih dalam tentang tindakan pemberdayaan sebagai panggilan gereja terhadap masalah kemiskinan yang dihadapi oleh umat.

Pada umumnya, masalah kemiskinan bukan lagi menjadi sesuatu yang baru di tengah kehidupan bersama.Secara harafiah, kata miskin diberi makna tidak berharta benda.Kemiskinan dapat diartikan sebagai struktur tingkat hidup yang rendah, mencapai tingkat kekurangan materi pada sejumlah atau golongan seseorang dibanding dengan standar hidup yang umumnya berlaku dalam masyarakat.Kemiskinan terjadi ketika terdapat ketidakmampuan untuk memenuhi kebutuhan, dasar seperti makanan, pakaian, tempat berlindung, pendidikan dan kesehatan. ${ }^{2}$ Masalah kemiskinan terjadi dari tahun ke tahun dan tidak diselesaikan secara tuntas oleh pihak-pihak terkait. Hal ini didukung oleh data dari Badan Pusat Statistik Maluku tentang jumlah penduduk miskin pada 11 kabupaten atau kota yang menunjukan bahwa angka tertinggi terdapat pada Kabupaten Maluku Tengah, yakni 74.800 ribu jiwa atau 20,04\% di tahun 2019. ${ }^{3}$ Salah satu wilayah di kabupaten Maluku Tengah yang memiliki tingkat kemiskinan tertinggi ialah wilayah Kabupaten Seram Utara dengan jumlah 7.173.460 atau 18,699\%.Oleh sebab itu, dengan tingkat kemiskinan tertinggi di daerah Maluku Tengah, maka masyarakat Seram Utara khususnya dusun Siahari menjadi lokus utama dalam penelitian ini. Dengan mengacu pada data tersebut, maka kemiskinan menjadi masalah sosial laten dalam masyarakat dan menarik perhatian berbagai kalangan akademisi dan praktisi yang meliputi pemerintah dan gereja.

Masyarakat dusun Siahari merupakan salah satu masyarakat pemilik Pulau Seram di wilayah kecamatan Seram Utara Timur Kobi, Kabupaten Maluku Tengah.Dalam status pemerintahan adat, masyarakat dusun Siahari merupakan anak negeri dari negeri Maneo. Mereka juga merupakan suatu komunitas masyarakat yang sudah beragama sejak lama dan seluruh anggota masyarakat menganut agama Kristen Protestan, sehingga masyarakat dusun Siahari disebut juga sebagai Jemaat Siahari yang berada dalam lingkup pelayanan Gereja Protestan Maluku di wilayah pelayanan Klasis Seram Utara.

Realitas yang dialami oleh masyarakat dusun Siahari sangat membutuhkan perhatian dari berbagai pihak, seperti gereja dan pemerintah.Berdasarkan pengamatan,

\footnotetext{
"Gereja di Jalan Keadilan: Fungsi Sosial Gereja Menghadapi Masalah Kemiskinan dan Ketumpangan Komunikasi di Bibir Pasifik," OSF Home (Oktober 2017).

2 Edi Suharto, Membangun Masyarakat Memberdayakan Rakyat: Kajian Strategis Kesejahteran Sosial dan Pekerjaan Sosial (Bandung: Refika Aditama, 2006), 131.

3 Badan Pusat Statistik Maluku, Jumlah Penduduk Miskin di Provinsi Maluku tahun 2017-2019. https://maluku.bps.go.id/indicator/23/162/1/jumlah-penduduk-miskin-di-provinsi-maluku-ribu-html. Data jumlah penduduk pada tahun 2020-2021 belum disajikan oleh Badan Pusat Statistik Maluku sehingga penulis masih menggunakan data tahun 2017-2019.
} 
mereka memiliki sumber daya alam yang sangat melimpah.Akan tetapi, kekayaan sumber daya alam tersebut tidak disertai dengan sumber daya manusia yang memadai untuk mengelola kekayaan tersebut.Hal ini juga diakui oleh salah seorang penduduk di Siahari bahwa ada banyak hasil panen yang dimiliki, namun mereka sulit untuk mengelolanya hingga tiba di tempat pemasaran.Kesulitan ini disebabkan oleh kurangnya sumber daya manusia dan akses trasnportasi yang tidak memadai. Perjalanan yang harus ditempuh untuk menuju dusun Siahari ialah mencapai dua belas kilometer dengan cara berjalan kaki karena akses jalan belum dibuka bagi penggunaan kendaraan roda dua maupun empat. Oleh sebab itu, akses transportasi juga menjadi masalah yang dihadapi oleh masyarakat di Siahari.

Selain masalah transportasi, masyarakat dusun Siahari juga mengalami masalah di bidang pendidikan dengan berbagai sarana-prasarana yang tidak menunjang proses belajar mengajar mereka. Bahkan hal lain yang dialami oleh masyarakat dusun Siahari juga mencakup sistem perekonomian dan kesehatan mereka. Hal ini terjadi ketika mereka mengalami peristiwa kebakaran hutan yang terjadi pada bulan Oktober tahun 2015 dan kematian masyarakat akibat busung lapar atau kurang gizi di tahun 2017.4 Oleh sebab itu, keterbatasan yang dialami mengakibatkan mereka berada dalam garis kemiskinan sehingga mengindikasikan bahwa masyarakat dusun Siahari sangat membutuhkan pemberdayaan dari pihak gereja dan pemerintah sebagai sebuah lembaga sosial yang memiki tujuan untuk mensejahterakan kehidupan masyarakat. Dalam hal ini, pemberdayaan dari pihak pemerintah berpusat pada pemerintahan kabupaten Maluku Tengah dengan berbagai program yang telah dicanangkan bersama. Sedangkan, dari pihak gereja lebih khusus Gereja Protestan Maluku dengan berbagai upaya pengembangan dan pemberdayaan umat yang tidak hanya terbatas pada diakonia karitatif atau pemberian bantuan semata. GPM harus lebih merujuk pada penerapan diakonia transformatif yang dapat menciptakan perubahan dari berbagai aspek kehidupan bagi masyarakat dusun Siahari. Hal ini bertujuan agar masyarakat di Siahari dapat memperoleh kesejahteraan dan hidup secara mandiri. Oleh sebab itu, gereja terpanggil untuk membebaskan umat dari kemiskinan melalui tindakan-tindakan pemberdayaan yang bersifat transformatif untuk menciptakan perubahan.

\section{Metode Penelitian}

Penelitian ini menggunakan model teologi praktis dari Richard R. Osmer dalam Practical Theology: An Introduction yang membagi empat tahapan untuk menganalisis di bidang teologis praktis, ${ }^{5}$ yakni Pertama, descriptive empirical task atau deskriptif kenyataan empiris. Kedua, interpretive task atau gambaran teoretis yang menjelaskan kenyataan-

\footnotetext{
${ }^{4}$ Hasil Wawancara dengan AK di Jemaat GPM Siahari pada 29 Oktober 2019.

5 Richard R Osmer, Practical Theology: An Introduction (Michigan: Grand Rapids, 2008), dalam Panduan Penulisan Tesis Program Pasca Sarjana Teologi UKIM, 17.
} 
kenyataan empiris menjadi masalah teologis. Ketiga, the normative task atau penggunaan berbagai konsep teologis untuk menafsirkan konteks, sistuasi dan membangun ajaran dari suatu praktik yang baik. Keempat, the pragmatic task atau menentukan strategi dari suatu aksi yang direncanakan untuk mempengaruhi serta membarui konteks problematis yang dikaji. Tahap pertama dan kedua merupakan bagian dari metode penelitian kualitatif. Metode penelitian dilakukan untuk memperoleh data yang valid dengan tujuan dan kegunaan tertentu. ${ }^{6}$ Jenis penelitian yang digunakan ialahjenis penelitian deskriptif analisis dengan menggunakan metode penelitian kualitatif. Metode kualitatif sebagai prosedur penelitian dapat menghasilkan data deskriptif berupa kata-kata tertulis atau lisan dari orang-orang dan perilaku yang dapat diamati. ${ }^{7}$ Sedangkan, tahap ketiga dan keempat digunakan untuk membangun konstruksi teologis. Pada bagian ini terdapat tindakan-tindakan praksis yang dapat digunakan oleh pihak gereja. Dengan kata lain, tahap ketiga dan keempat akan menjelaskan cara-cara untuk melakukan tindakan pemberdayaan yang dilakukan oleh gereja.

Penelitian ini berlangsung di Dusun Siahari, Kecamatan Seram Utara Timur Kobi.Dalam hal ini, penulis lebih berfokus pada masalah-masalah kemiskinan yang terjadi di Dusun Siahari, Kecamatan Seram Utara Timur Kobi.Dalam penelitian ini, penulis menggunakan beberapa teknik pengumpulan data, yakni teknik observasi, wawancara, dokumentasi dan studi pustaka. Pada teknik yang pertama, penulis akan mengobservasi keberadaan masyarakat Dusun Siahari yang mengalami masalah kemiskinan. Pada teknik yang kedua, penulis akan mewawancarai beberapa informan kunci yang telah dijabarkan pada poin sumber data guna untuk mendapatkan data-data yang valid terkait permasalahan yang diteliti. Pada teknik yang ketiga, penulis mendokumentasikan lokus penelitian serta keberadaan masyarakat Dusun Siahari.

\section{Hasil dan Pembahasan}

Masalah Kemiskinan yang dihadapi oleh Masyarakat Dusun Siahari Kecamatan Seram Utara Timur Kobi

Masalah kemiskinan merupakan masalah yang konkrit dihadapi oleh masyarakat hingga sekarang ini. Dalam penelitian yang dilakukan, penulis menemukan bahwa masyarakat dusun Siahari mengalami beberapa masalah yang mengakibatkan mereka berada dalam kondisi miskin. Pertama, masalah pendidikan. Dusun Siahari hanya memiliki dua bangunan gedung sekolah yang terdiri dari SD dengan 3 ruang belajar dan SMP dengan 3 ruang belajar. Mereka tidak memiliki bangunan gedung SMA. ${ }^{8}$ Bahkan mereka juga mengalami keterbatasan tenaga guru. Sejauh ini, proses pembelajaran dilakukan oleh mereka yang bukan berlatarbelakang ilmu keguruan. Keterbatasan seperti ini

\footnotetext{
${ }^{6}$ Sugiyono, Metode Penelitian Kuantitatif, Kualitatif dan R\&D (Bandung: Alfabeta, 2013), 2.

${ }^{7}$ Lexy J. Moleong, Metodologi Penelitian Kualitatif (Bandung: Rosdakaria, 1998), 3.

${ }^{8}$ Hasil Wawancara dengan JI di dusun Siahari pada 28 Juli 2019.
} 
mengakibatkan proses belajar mengajar di sekolah menjadi terhambat dan tidak efektif. Realitas yang dialami oleh masyarakat dusun Siahari menunjukan bahwa akses pendidikan masih sangat terbatas. Padahal, pendidikan merupakan salah satu kebutuhan pokok yang harus dipenuhi oleh setiap orang. Undang-undang Nomor 20 tahun 2003 Pasal 5 menegaskan bahwa setiap warga negara mempunyai hak yang sama untuk memperoleh pendidikan yang bermutu. Apabila ditinjau dari jumlah penduduk berdasarkan tingkat pendidikan di dusun Siahari, terlihat penduduk yang sedang bersekolah sebanyak 58 orang yang terdiri dari 39 orang sedang belajar di tingkat SD, 12 orang sedang belajar di tingkat SMP, 4 orang sedang belajar ditingkat SMA dan 2 orang sedang belajar di Perguruan Tinggi. Sedangkan penduduk dusun Siahari yang tidak berpendidikan dan terindikasi buta aksara sebanyak 33 orang, dengan sebaran terbanyak pada kelompok usia produktif antara 15 tahun - 45 tahun sebanyak 23 orang dan antara 45-70+ sebanyak 10 orang. Penulis berpendapat bahwa seseorang disebut sebagai buta aksara berarti tidak memiliki kemampuan untuk membaca dan menulis.Realitas seperti ini menjadi sebuah masalah yang harus diatasi dengan serius agar dapat memutuskan mata rantai buta aksara sehingga tidak mempengaruhi anak-anak di generasi berikutnya.Oleh sebab itu, sangat dibutuhkan tenaga guru dengan bidang keahlian masing-masing untuk mengajarkan masyarakat dusun Siahari mulai dari teknik membaca, menulis, dan sampai pada tingkat mata pelajaran yang ada sesuai dengan kurikulum.

Kedua, masalah kesehatan. Berdasarkan hasil penelitian yang dilakukan, ditemukan bahwa sejauh ini masyarakat di dusun Siahari belum memiliki saranaprasarana kesehatan berupa poliklinik atau puskesmas dan alat-alat kesehatan. Hal ini tentu mempengaruhi akses pemeriksaan kesehatan masyarakat setempat. Apabila kedapatan ada warga yang jatuh sakit, maka pemeriksaan kesehatan dan pengobatan bagi yang sakit dapat dilakukan di Puskesmas Bantu (PusTu) yang terletak di transmigrasi J9 dengan jarak yang harus ditempuh untuk mencapai lokasi Puskesmas Bantu ialah sejauh $\pm 12 \mathrm{Km}^{10}$ atau ke puskesmas yang berada di desa Morokai yang berjarak kurang lebih \pm $17 \mathrm{Km}^{11}$. Realitas ini menunjukan bahwa pemerintah Dinas Kesehatan belum memiliki perhatian yang penuh untuk memperhatikan tingkat kesehatan daerah-daerah terpencil, khususnya daerah pegunungan di Pulau Seram. Berbanding terbalik dengan Undangundang Nomor 36 Tahun 2009 Pasal 15 yang menegaskan bahwa pemerintah bertanggung jawab atas ketersediaan lingkungan, tatanan, fasilitas kesehatan baik fisik maupun sosial bagi masyarakat untuk mencapai derajat kesehatan yang setinggi-

\footnotetext{
9 Transmigrasi J merupakan wilayah transmigrasi yang terdiri dari kelompok pendatang dari pulau Jawa dan bergabung dengan masyarakat lokal dari dusun Maneo. Akan tetapi, kini masyarakat dari Maneo memilih keluar dari transmigasi J dengan alasan sulit menyesuaikan cara hidup dengan para pendatang;

${ }^{10}$ Hasil Wawancara dengan AT sebagai Kepala Dusun Siahari pada 29 Juli 2019.

${ }^{11}$ Hasil Wawancara dengan SI sebagai Saniri Dusun Siahari pada 29 Juli 2019.
} 
tingginya. Artinya bahwa pemerintah wajib menjawab kebutuhan masyarakat khususnya di bidang kesehatan. Apabila belum memiliki poliklinik atau pun puskesmas, pemerintah seharusnya menyediakan pos-pos khusus sebagai bantuan pemeriksaan darurat ketika masyarakat Siahari mengalami gangguan kesehatan.

Ketiga, masalah ekonomi.Dalam keseharian, masyarakat dusun Siahari rata-rata melakukan aktivitas meramu, berburu dan bercocok tanam sebagai matapencaharian utama mereka.Artinya, aktivitas meramu, berburu bercocok tanam dijadikan sebagai sarana untuk pemenuhan kebutuhan hidup sehari-hari.Apabila dikelola dengan baik, hasil produksi yang diperoleh dari aktivitas pertanian masyarakat dusun Siahari tidak hanya terbatas pada sebuah usaha untuk menghidupi keluarga dalam pemenuhan kebutuhan sandang dan pangan.Hasil produksi dari pertanian tersebut justru dapat memperoleh keuntungan untuk membantu tingkat perekonomian mereka.Akan tetapi, hal ini tidak dapat berjalan dengan maksimal karena sumber daya manusia untuk mengelola hasil-hasil tersebut di dusun Siahari masih sangat berkurang.Keterbatasan sumber daya manusia turut dipengaruhi oleh tingkat pendidikan masyarakat, sehingga mereka tidak memiliki skill untuk mengurusnya hingga tiba pada pemasaran.Tidak hanya pada keterbatasan sumber daya manusia, jarak pasar yang jauh dari dusun Siahari dan juga kesulitan mengakses transportasi menyebabkan petani sulit untuk mengelola hasil produksi di dunia pemasaran. Apabila hasil produksi tersebut disalurkan ke pasar dengan menggunakan jasa ojek dan melintasi medan yang begitu berat dengan biaya sebesar Rp. 50.000,- maka kemungkinan besar para petani hanya memperoleh penghasilan yang sangat sedikit. Apalagi ketika nilai jual di pasar rendah, maka sudah pasti penghasilan yang diperoleh pun akan sangat dipengaruhi. Hal ini berarti bahwa para petani dusun Siahari berada pada titik dilema antara membawa hasil panen untuk dijual tetapi memperoleh penghasilan yang rendah, ataukah membiarkan hasil panen di rumah tetapi akan menjadi busuk sehingga mereka mengalami kerugian. Dengan demikian, tingkat pendapatan ekonomi mereka tidak menetap.

Keempat, masalah infrastruktur. Berdasarkan penelitian yang dilakukan, penulis menemukan bahwa ada banyak kekurangan dalam pembangunan infrastruktur yang terjadi di dusun Siahari, seperti transportasi, rumah, air bersih dan tenaga listrik. Sejauh ini, masyarakat dusun Siahari tidak memiliki jalur jalan yang memadai sebagai akses utama untuk melakukan perjalanan ke tempat lain. Mereka cenderung berjalanan melalui jalan-jalan alternatif dengan cara berjalan memasuki hutan-hutan hingga menembusi jalan utama yang diakses oleh PT. Nusa Ina Group. Tentu perjalanan seperti ini membutuhkan tenaga dan waktu yang panjang sehingga aktivitas mereka terkadang menjadi terganggu hanya karena jarak jauh yang harus ditempuh dan kondisi jalan akibat situasi hujan. Dengan demikian, akses transportasi untuk mencapai dusun Siahari dapat dicapai dengan berkendaraan roda dua dan empat pada waktu musim kemarau, tetapi jika musim hujan hanya dapat dicapai dengan berjalan kaki dari batas jalan beraspal di 
perkebunan kepala sawit atau PT. Nusa Ina Group sejauh $10 \mathrm{~km}$. Sedangkan infrastruktur rumah, masyarakat dusun Siahari tidak memiliki bangunan rumah sebagai tempat tinggal yang tetap. Mereka cenderung hidup sebagai masyarakat nomaden di hutan Pulau Seram yang selalu berpindah dari satu tempat ke tempat yang lain. Akan tetapi, pada tahun 2005Pemerintah Dinas Sosial Kabupaten Maluku Tengah dan Provinsi Maluku memberikan bantuan berupa rumah yang terbuat dari papan kepada Komunitas Adat Terpencil di dalamnya termasuk masyarakat dusun Siahari sebanyak 61 rumah. Selain itu, air yang digunakan untuk memenuhi kebutuhan hidup sehari-hari juga diakses melalui aliran air sungai. Mereka juga mengambil air tersebut untuk kebutuhan masak dan minum. Akan tetapi, apabila terjadi hujan maka mereka memilih untuk menampung dan mengolahnya untuk pemenuhan kebutuhan sehari-hari. Tindakan yang dilakukan oleh masyarakat dusun Siahari tentu akan berdampak buruk bagi kesehatan mereka.

Berdasarkan masalah-masalah yang telah dipaparkan di atas, maka dapat dikatakan bahwa realitas hidup masyarakat dusun Siahari berada pada tingkat kemiskinan. Hal ini sejalan dengan beberapa indikator kemiskinan yang dipaparkan oleh Badan Perencanaan Pembangunan Nasional atau Bappenas, yakni keterbatasan pangan; keterbatasan akses kesehatan; keterbatasan akses pendidikan; keterbatasan akses pekerjaan; keterbatasan akses terhadap air bersih; dan tidak adanya jaminan rasa aman. Masyarakat dusun Siahari mengalami keterbatasan dalam berbagai hal seperti mengakses pendidikan, kesehatan, ekonomi, transportasi dan pembangunan infrastruktur dusun. Keterbatasan ini disebabkan oleh tingkat sumber daya manusia yang rendah, kelalaian pemerintah terhadap masyarakat-masyarakat yang terpencil dan kesadaran untuk mengembangkan diri secara maksimal. Oleh sebab itu, dapat dikatakan bahwa masyarakat dusun Siahari mengalami kemiskinan secara absolut yang terjadi karena tingkat pendapatan tidak dapat mencukupkan kebutuhan hidup.Masyarakat dusun Siahari juga mengalami kemiskinan secara relatif akibat pembangunan dari pemerintah yang belum menjangkau seluruh masyarakat.Akibat dari eksistensi pemerintah yang belum menjangkau, secara struktural, pemerintah tidak melakukan tugas pokok dan fungsi dalam tindakan pembangunan desa terpencil dengan baik.Pemerintah membatasi ruang gerak masyarakat dusun Siahari dengan keterbatasan akses-akses pembangunan.Tindakan pemerintah terkait pembangunan secara fisik cenderung dilakukan pada wilayah-wilayah transmigrasi.Hal ini menunjukan bahwa masyarakat dusun Siahari mengalami ketidakadilan yang terjadi akibat dari tindakan diskriminasi pemerintah.Realitas seperti ini mengindikasikan bahwa masyarakat dusun Siahari juga mengalami kemiskinan struktural.Bertolak dari tindakan ketidakadilan yang dilakukan oleh pemerintah, masyarakat dusun Siahari juga memiliki sikap apatis terhadap tindakan pembangunan.Dengan demikian, realitas yang dihadapi menunjukan bahwa mereka berada pada tingkatan hidup keluarga prasejahtera yang mengalami 
kekurangan pemenuhan kebutuhan sandang, pangan, papan; menetap di rumah yang tidak layak huni; kekurangan sarana prasarana kesehatan dan pendidikan; dan juga aspek-aspek penunjang lainnya. Apabila masalah-masalah seperti ini tidak ditindaklanjuti maka masyarakat dusun Siahari akan tetap menambah angka kemiskinan. Dengan kata lain, mata rantai kemiskinan di dusun Siahari tidak diputuskan melainkan masih terus meningkat.

\section{Kehadiran Yesus sebagai Figur yang membebaskan umat dari Kemiskinan}

Masalah kemiskinan yang dihadapi oleh umat di Siahari merupakan masalah iman yang mengharuskan gereja untuk melakukan tindakan pemberdayaan dalam dimensi kekristenan yang berlandas pada kasih Allah. Dalam persoalan kemiskinan, eksistensi gereja bukan sebagai kantor sosial tetapi memikul tanggung jawab sosial. Gereja tidak menganggap kemiskinan sebagai sesuatu yang menjijikan, yang tidak perlu dibicarakan dan diselesaikan. Secara eklesiologis, gereja diharapkan untuk memperhatikan orangorang kecil, yang mengalami perlakuan tidak adil, dan lemah. Hal ini biasanya disebut preferential option for the poor yang diterjemahkan sebagai mendahulukan orang-orang miskin. ${ }^{12}$ Dengan demikian, gereja harus memiliki komitmen untuk tidak meninggalkan mereka yang miskin dan lemah, seperti umat di Siahari.

Kata "miskin" dalam Alkitab memiliki pengertian ganda. Penyebutan kata "miskin" dalam Alkitab cenderung pada sebutan orang miskin dan kemiskinan. Arti yang pokok dari kemiskinan ialah keadaan yang buruk dan keji yang menghina martabat manusia dan berlawanan dengan kehendak Allah. Dalam perjanjian lama, kata "miskin" disebut dalam beberapa kata, yakni ebyon berarti orang yang menginginkan dan membutuhkan sesuatu; dal berarti orang yang lemah dan tidak berdaya; ani berarti orang yang diperas oleh orang lain. Sedangkan dalam Perjanjian Baru, kata "miskin" dalam bahasa Yunani disebut ptoks berarti orang yang begitu melarat sehingga tidak dapat hidup kecuali mengemis. ${ }^{13}$ Menurut kesaksian Alkitab, yang dimaksud dengan "orang-orang miskin" adalah orang-orang yang tidak mempunyai apa-apa dan menjadi lapisan yang paling bawah dari masyarakat.Sentral dari kemiskinan ialah kekurangan atau ketiadaan kemungkinan-kemungkinan hidup materill. ${ }^{14}$ Selain itu, Alkitab juga menyatakan bahwa kemiskinan dapat disebabkan oleh kemalasan (Ams. 6: 9-11; 24: 30-34; 19:15), kemabukan, kebodohan, dan kerakusan (Ams. 23: 20-21; 21: 17; 13: 18, 28; 28 : 19). ${ }^{15}$ Kemiskinan tidak dianggap sebagai kehendak Allah.Allah justru melawan

12 Emanuel Gerrit Singgih, Berteologi dalam Konteks (Yogyakarta: Kanisius, 2000), 214-215.

13 Malcolm Brownlee, Tugas Manusia Dalam Dunia Milik Tuhan (Jakarta: BPK Gunung Mulia, 2011),

81.

14 J. L. Ch. Abineno, Apa Kata Alkitab? I (Jakarta: BPK Gunung Mulia, 1981), 43.

15 Brownlee, Tugas Manusia Dalam Dunia Milik Tuhan, 81. 
kemiskinan dan memanggil umat-Nya untuk menentangnya. ${ }^{16}$ Dengan demikian, kemiskinan tidak didatangkan oleh nasib atau kehendak Allah.

Menanggapi masalah kemiskinan yang dialami oleh umat di Siahari dan berlandas pada refleksi teologi iman Kristen, maka pokok penting yang harus direfleksikan pertama, kemiskinan akan berakhir ketika kebutuhan dasar umat terpenuhi. Dalam hal ini, Tuhan menjadi sumber harapan yang akan memberikan berkat-Nya untuk mencukupkan segala sesuatu. Manusia sendiri tidak dapat melakukan segala sesuatu dalam ketidakberdayaan dan kelemahan.Oleh sebab itu, injil Lukas menegaskan bahwa orang-orang yang menderita dalam kemiskinan adalah orang-orang yang tidak mempunyai jaminan di dunia dan pengaruh apapun tetapi memiliki keselamatan dalam Allah.Dalam realitas yang dihadapi oleh Jemaat GPM Siahari, mereka tidak memiliki kuasa dan jaminan untuk hidup sejahtera tanpa adanya pengharapan di dalam Alah.Sebab itu, dalam pengaharapan mereka terhadap Allah, mereka tidak akan dikecewakan dan dibiarkan untuk terus hidup dalam keadaan miskin Kedua, keadilan Kristen bagi kaum miskin.Penyelesaian kemiskinan tidak dapat dipisahkan dari seruan keadilan Allah. Keadilan lebih merujuk pada apa yang dilakukan oleh Allah, sebab keadilan adalah hakikat Allah. Artinya, Allah bertindak secara konsisten dengan sifat-Nya.Dalam keadilan, tindakan-tindakan penyelamatan Allah diwartakan melalui hukum-hukum-Nya dan juga melalui jenis hubungan-hubungan antara manusia yang dikehendaki-Nya. ${ }^{17}$ Keadilan Allah tidak hanya dinyatakan kepada perorang, melainkan kepada seluruh bangsa kepunyaan-Nya.Oleh sebab itu, berlaku adil menunjukan bahwa keseluruhan umat menjadi bagian dari satu tubuh untuk mengalami pembebasan dari penderitaan. ${ }^{18}$

Keadilan Allah yang dinyatakan melalui Yesus menunjukan bahwa Allah sungguh solider dengan kaum miskin. Ia lahir dalam lingkungan sosial yang miskin (bdk. Luk 2:120). Tentu saja Yesus memilih gaya hidup miskin bukan karena kemiskinan menjadi sesuatu yang ideal, tetapi demi solidaritas dengan kaum miskin dan demi pembebasan manusia dari kemiskinan. ${ }^{19}$ Sebab Yesus juga mengidentifikasi diri-Nya sebagai seorang yang hina, yang tertindas, dan orang miskin yang lemah dalam rupa-rupa situasi, sehingga barangsiapa yang melayani mereka, ia juga melayani Yesus. ${ }^{20} \mathrm{Hal}$ ini kemudian menunjukan bahwa Yesus telah menyatakan diri-Nya sebagai pembebas kaum miskin.Ia berjuang di pihak kaum miskin dan tertindas. Dalam konteks umat dusun Siahari, keadilan Allah melalui Yesus diwartankan melalui kehadiran gereja yang menjadi agen pembebas umat dari kemiskinan. Keadilan Allah tidak hanya diwartakan melalui

\footnotetext{
${ }^{16}$ Brownlee, Tugas Manusia Dalam Dunia Milik Tuhan, 82.

${ }^{17}$ J. Andrew Kirk, Apa itu Misi? Suatu Penelusuran Teologis (Jakarta: BPK Gunung Mulia, 2012), 142. ${ }^{18}$ Kirk, Apa itu Misi? Suatu Penelusuran Teologis, 143.

${ }^{19}$ Martin Chen, Teologi Gustavo Gutierrez: Refleksi dari Praksis Kaum Miskin (Yogyakarta: Kanisius, 2002), 99.

${ }^{20}$ Krido Siswanto, "Tinjauan Teoritis dan Teologis terhadap Diakonia Transformatif Gereja”, Jurnal Simpson 1. No. 1 (2014), 102.
} 
pemberitaan di mimbar-mimbar pelayanan, melainkan lebih pada tindakan nyata yang menyentuh kehidupan umat dusun Siahari.Oleh sebab itu, wajah Allah melalui diri Yesus hadir sebagai pembebas yang membebaskan penderitaan umat di dusun Siahari.

\section{Pemberdayaan sebagai Panggilan Gereja dalam Memberdayakan Kaum Miskin}

Dalam melakukan tugas dan tanggung jawab gereja sebagai sebuah lembaga, maka peran dan fungsi gereja ialah untuk memperjuangkan hak-hak hidup umat manusia. Gereja diutus ke dalam dunia untuk terlibat dalam perjuangan mewartakan Allah kehidupan di tengah sejarah kemiskinan. Dengan kata lain, amanat gereja untuk menghadirkan tandatanda kerajaan Allah di tengah-tengah dunia mengharuskan gereja untuk terlibat dan berpartisipasi aktif dalam upaya mengatasi masalah kemiskinan. Dalam hal ini, Gereja Protestan Maluku terpanggil untuk membebaskan umat dari masalah-masalah kemanusiaan khususnya masalah kemiskinan.GPM harus menjadi sumber kesejahteraan dalam tindakan pemberdayaan agar dapat menciptakan perubahan bagi kehidupan bersama.

Tindakan pemberdayaan yang dilakukan dalam dimensi bergerja harus didasarkan pada ajaran-ajaran Kristen seperti kesejahteraan, kebenaran dan keadilan. GPM juga dapat mengacu pada tiga hakekat tugas panggilan gereja, yakni: ${ }^{21}$ pertama, tugas panggilan gereja mengharuskan gereja untuk hidup berpadanan dengan Injil dan berdiri teguh dalam satu roh, dan mengharuskan gereja-gereja sebagai satu tubuh, sehati sepikir berjuang untuk iman yang ditumbulkan oleh berita injil dan mengharuskan mereka saling memahami, memperhatikan dan melayani demi kepentingan bersama (Flp. 1: 27; 2:4; 1 Kor. 12: 27). Inilah yang menjadi tugas keesaan, yakni membarui, membangun dan mempersatukan gereja.Kedua, tugas panggilan gereja adalah menyampaikan Injil Yesus Kristus, yaitu Injil perdamaian sebagai kekuatan Allah yang menyelamatkan dan memperdamaikan segala sesuatu dengan Allah (Rm. 1: 16-17; Kol. 1:20). Hal ini berarti bahwa gereja harus memberitakan Injil, yaitu berita tentang Allah Yesus Kristus yang memberlakukan keadilan dan kebenaran-Nya yang menyelamatkan, yang menuntut pertobatan, yang memberikan keadilan-Nya kepada orang-orang miskin dan tertindas, yang mengaruniakan kesejahteraan kepada segala bangsa dan segala makhluk (Luk. 24: 47; Mrk. 16: 15) sebagai bagian dari karya menyeluruh Yesus Kristus yang memperdamaikan dan memulihkan segala sesuatu ke dalam persekutuan yang harmonis dengan Allah dan sesamnya. Inilah tugas pemberitaan atau pekabaran Injil yang menjadi bagian dari keseluruhan misi gereja di dunia ini. Ketiga, tugas panggilan gereja mengharuskan gereja memerangi segala penyakit, kelemahan dan ketidakadilan dalam masyarakat. Gereja berkewajiban untuk mengusahakan dan memelihara secara bertanggung jawab akan sumber-sumber alam dan lingkungan hidup. Inilah tugas

21 PGI, Dokumen Keesaan Gereja: Persekutuan Gereja-gereja di Indonesia 2014-2019 (Jakarta: Gunung Mulia, 2015), 43-44. 
pelayanan dalam kasih serta keadilan. Dengan mengacu pada ketiga poin tersebut, maka GPM terpanggil untuk mewartakan kehendak Allah yang termanifestasi dalam kehidupan bersama. GPM turut terlibat dalam realitas hidup Jemaat GPM Siahari sebagai masyarakat miskin dan melakukan tindakan pemberdayaan terdahap mereka demi mensejahterakan hidup bersama.

Dalam melakukan tindakan pemberdayaan bagi kaum miskin, GPM dapat mengacu pada ajaran-ajaran gereja yang menekankan pada kemiskinan.GPM menegaskan bahwa kemiskinan bukanlah suatu kutukan dari Allah.Allah justru berpihak kepada kaum miskin dan papa dan mengidentifikasikan diri-Nya dengan mereka yang miskin dan menderita (Mat. 25:31 dst). Allah menghendaki agar supaya kemiskinan dieliminasi dan mereka yang miskin harus diberdayakan demi memperoleh kehidupan yang lebih bermartabat (Ul. 15:1-11,15:12-18 dll, Amos 4:1, 5:11a, 24, Yes. 1:17, Mat. 15;32-39, Mrk. 8:1-10, Luk. 4:18-19).Oleh sebab itu, gereja sebagai wujud pemerintahan Allah di dunia harus berada di pihak kaum miskin demi membebaskan orang-orang miskin dari penderitaan mereka.Gereja harus berada di jalan Yesus untuk bekerja melakukan tugas membantu orang miskin keluar dari kemiskinan mereka.Gereja harus melakukan tugas pendampingan untuk membantu para miskin dalam memperjuangkan martabat dan hak hidupnya. ${ }^{22}$ Berdasarkan hal inilah, GPM sesuai amanat pelayanan untuk memberitakan kepada segala makluk harus membangun komitmen bersama pemerintah, semua agama, denominasi gereja dan unsur-unsur lainnya dalam masyarakat untuk mengusahakan pembebasan dari kemiskinan, kebodohan dan keterbelakangan. ${ }^{23}$

Tindakan pemberdayaan melalui relasi kemitraan antar jemaat harus disertai dengan beberapa peran dan fungsi gereja, yakni pertama, gereja sebagai fasilitator.Dalam hal ini, GPM bertindak sebagai fasilitator yang memfasilitasi kaum miskin dengan sejumlah kelengkapan maupun kesempatan untuk keluar dari ketidakberdayaan mereka.Kedua, gereja sebagai mediator.GPM harus menjembatani kaum miskin dengan pihak-pihak terkait seperti pemerintah dalam kepentingan hak-hak hidup mereka.Ketiga, gereja sebagai transformator.Dalam hal ini, GPM menerapkan fungsi edukasi melalui tindakan pemberdayaan disertai dengan pelaksanaan monitoring-evaluasi.Peran dan fungsi ini membutuhkan waktu yang panjang sehingga tidak hanya dilakukan dalam situasi-situasi tertentu.Dengan demikian, umat di Siahari sebagai masyarakat miskin tidak berjalan sendiri dalam memperjuangkan kesejahteraan hidup mereka melainkan ada bersama dengan pihak gereja sebagai agen pemberdayaan.

Berdasarkan peran dan fungsi gereja dalam melakukan tindakan pemberdayaan terhadap masyarakat miskin di Siahari, maka ada beberapa langkah praktis yang dapat

\footnotetext{
22 Ajaran Gereja Protestan Maluku Nomor 584 tentang Tugas Gereja terhadap Orang Miskin.

23 Tata Gereja Protestan Maluku Bab IV tentang Amanat, Pola dan Perencanaan Pelayanan Gereja, Pasal 8 tentang Amanat Pelayanan GPM.
} 
dilakukan, yakni: Pertama, gereja membentuk sebuah tim pemberdayaan melalui Seksi Pekabaran Injil dan Pelayanan Kasih (PIPK) di tingkat Jemaat dengan melibatkan orangorang yang memiliki kemampuan di bidang pendidikan, kesehatan, pertanian, dan ekonomi. Tujuan dari pembentukan tim ini ialah untuk membangun kerja sama yang dapat memberdayakan umat hingga tercipta perubahan dari berbagai aspek kehidupan demi kesejahteraan hidup mereka. Kedua, tim pemberdayaan melakukan observasi pada lokasi yang ditetapkan sebagai sasaran pelaksanaan pemberdayaan. Ketiga, tim pemberdayaan melakukan identifikasi terhdap masalah-masalah yang ditemukan selama masa observasi. Keempat, tim pemberdayaan menentukan strategi atau misi dari pelaksanaan tindakan pemberdayaan. Hal ini dilakukan agar mempermudah pengembangan kebijakan dan perencanaan tindakan pemberdayaan sehingga pelaksanaannya menjadi lebih terarah dan terstruktur. Kelima, tim pemberdayaan menentukan arah kebijakan yang dilandaskan pada strategi pelaksanaan tindakan pemberdayaan. Keenam, tim pemberdayaan menyusun program dan kegiatan yang dapat memberdayakan umat dari ketidakberdayaan mereka. Ketujuh, tim pemberdayaan melakukan monitoring-evaluasi dalam jangka waktu 3 bulan atau 6 bulan sekali dalam setahun. Hal ini bertujuan untuk mengetahui sejauh mana kaum miskin telah mengalami transformasi guna kesejahteraan hidup mereka.

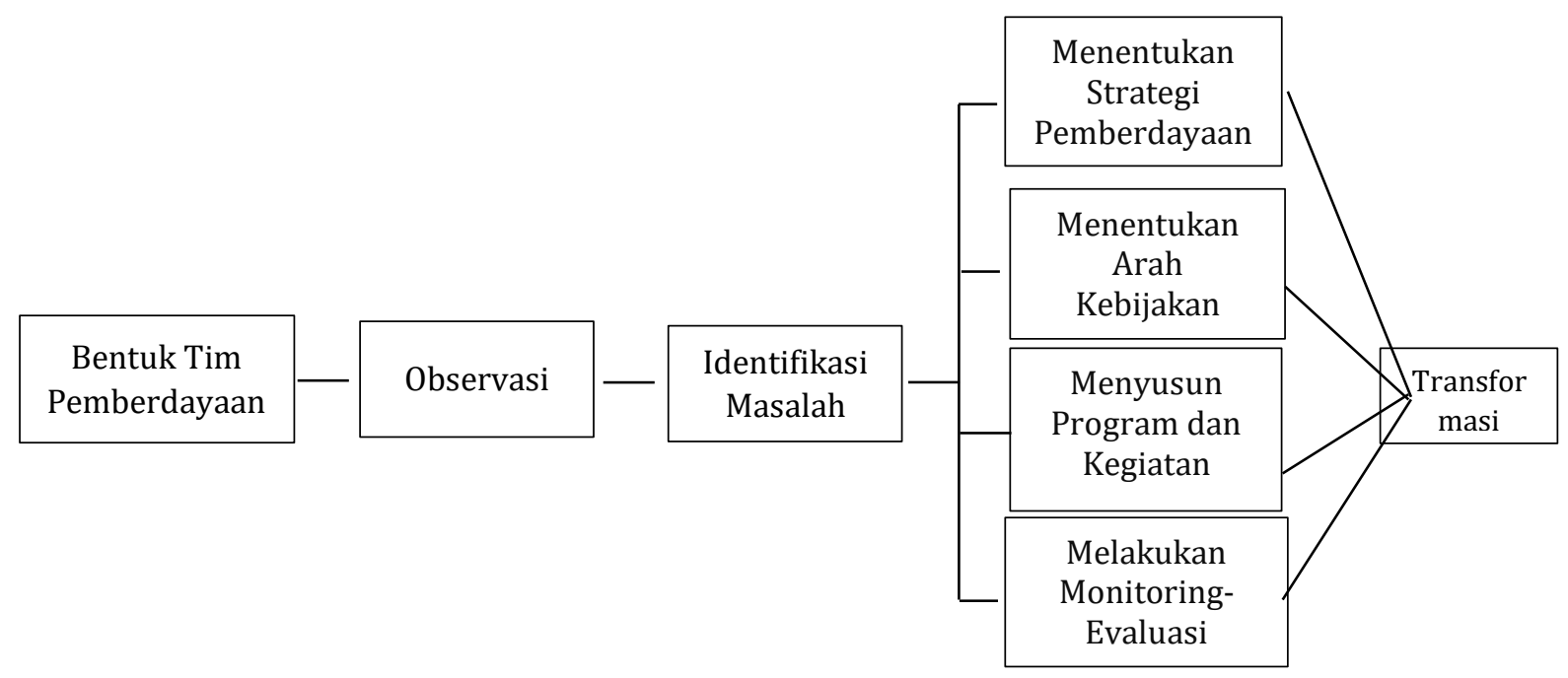

\section{Bagan 1. Alur Pelaksanaan Tindakan Pemberdayaan}

Tindakan pemberdayaan yang dilakukan harus mencakup aspek spiritualitas umat yang ugahari agar dapat memupuk etos hidup berkecukupan. Spiritualitas keugaharian digunakan sebagai gaya hidup alternatif umat kristiani dalam konteks hidup sekarang ini. Dalam hal ini, "keugaharian" yang dipahami tidak hanya dalam arti "kesederhanaan", melainkan lebih pada gagasan tentang etos hidup "berkecukupan" atau self-sufficient. Spiritualitas tersebut lahir dari penghayatan terhadap Doa Bapa Kami yang diajarkan Yesus, "berilah kami pada hari ini, makanan kami yang secukupnya" (Mat. 5: 11). ${ }^{24}$ Dengan

${ }^{24}$ PGI, Potret dan Tantangan Gerakan Oikumene (Jakarta: BPK Gunung Mulia, 2015), 86. 
spiritualitas, gereja dalam pelayanannya harus solider dengan orang miskin dan tertindas. Solidaritas berarti keterlibatan orang percaya atau gereja dalam ikut merasakan dan menanggung kemiskinan dan penderitaan yang dialami oleh umat manusia. Pelayanan dan solidaritas gereja sungguh-sungguh otentik apabila gereja rela menjadi "miskin", seperti Kristus yang telah memiskinkan diri-Nya dan mengambil rupa seorang hamba. Gereja yang dimaksud adalah gereja yang berbela rasa dan berpraksis bagi orang miskin dan lemah. Perjuangan Gereja tidak lain ialah agar manusia memiliki nilai "kemanusiaannya" sebagai manusia yang diciptakan serupa dengan gambar Allah. Dalam hal ini, gereja dapat melakukan pemberdayaan melalui pelayanan kasih yang terwujud dalam bentuk diakonia.Umumnya, ada tiga bentuk diakonia yang dilakukan oleh pihak gereja, yakni diakonia karitatif, diakonia reformatif dan diakonia transformatif.Dalam menyikapi masalah kemiskinan, gereja harus fokus melakukan pelayanan diakonia transformatif dibanding kedua bentuk yang lainnya.Hal ini disebabkan oleh pemberlakuan diakonia karitatif dan reformatif yang lebih bersifat sementara dan tidak memberdayakan orang-orang yang membutuhkan.Kedua bentuk diakonia tersebut diwujudkan dalam bentuk pemberian makanan dan pakaian, menghibur orang-orang sakit dan melakukan berbagai perbuatan amal lainnya. Dengan kata lain, kedua bentuk diakonia tersebut hanya berlaku secara situasional apabila terjadi insiden-insiden tertentu.

Diakonia transformatif merupakan pelayanan dari pihak gereja kepada rakyat kecil yang mengalami patah semangat dalam berjuang. ${ }^{25}$ Pelayanan tersebut dilakukan dengan tujuan untuk menyadarkan hak-hak mereka dan memberdayakan mereka.Diakonia transformatif dilakukan dengan fokus utama kepada rakyat sebagai subjek sejarah dan bukan objek; tidak karitatif tetapi preventif; tidak didorong oleh belas kasihan tetapi keadilan; mendorong partisipasi rakyat; melakukan penyadaran pada rakyat; dan mengorganisasi rakyat. ${ }^{26}$ Diakonia transformative harus menjadi sebuah pelayanan gereja secara bersama.Kehadiran gereja dan diakonia transformatif juga tidak hanya berfokus pada individual, tetapi pada kelompok masyarakat yang mencakup kehidupan semua orang yang mengalami penderitaan akibat kemiskinan. ${ }^{27}$ Oleh sebab itu, melalui diakonia transformatif gereja dapat menjadi sentral di tengah masyarakat yang membebaskan dan memberdayakan orang-orang lemah.

Dalam upaya melakukan pembangunan jemaat melalui tindakan pemberdayaan gereja dapat bergandeng tangan dengan pemerintah untuk memberdayakan kaum miskin dengan tetap mengacu pada alur pelaksanaan tindakan pemberdayaan (bagan 1). Kerja sama antara gereja dan pemerintah juga dilakukan dengan tujuan untuk menciptakan

${ }^{25}$ Widyatmadja, Yesus dan Wong Cilik, 48.

${ }^{26}$ Widyatmadja, Yesus dan Wong Cilik, 49.

${ }^{27}$ Josef Hehanussa, "Pelayanan Diakonia yang Transformatif: Tinjauan Kritis terhadap Pelaksanaan Diakonia Gereja” Jurnal Gema 36. No. 1 (2012), 136. 
keadilan, perdamaian, dan keutuhan ciptaan. Ajaran Gereja Protestan Maluku menegaskan bahwa gereja dan pemerintah yang berada di bawah payung negara dapat bekerja sama dalam beberapa hal, yakni untuk mengusahakan kesejahteraan manusia dan semua ciptaan (Yer. 29: 7); menegakan hukum, keadilan, kebenaran, dan hak asasi manusia (Am. 5: 15 dan 24); dan memperkuat masyarakat berkeadaban (Rm. 12: 9-21; 13: 1-7). Oleh sebab itu, dalam upaya untuk melakukan tindakan pemberdayaan, maka gereja dan pemerintah dapat bergandeng tangan untuk mensejahterakan kehidupan bersama. $^{28}$

Gereja dan pemerintah harus bersifat terbuka terhadap masalah kemiskinan dan dapat menggunakan alur pelaksanaan tindakan pemberdayaan (lih. bagan 1) sebagai bentuk alternatif penerapan pemberdayaan. Dalam penerapannya, gereja dan pemerintah harus menaruh perhatian dan berfokus pada masyarakat miskin. Setelah itu, gereja dan pemerintah juga harus cermat dan teliti untuk membedah masalah kemiskinan. Hal ini dilakukan dengan tujuan untuk memperoleh sejumlah data yang dapat dijadikan sebagai acuan untuk penyusunan strategi tindakan pemberdayaan dari pihak pemerintah dan gereja. Strategi yang disusun haruslah berupa tindakan-tindakan yang menjawab persoalan pada aspek sosio-ekonomi dan spiritual. Dengan demikian, hasil dari tindakan pemberdayaan yang dilakukan oleh kedua pihak dapat menciptakan transformasi secara holistik yang memberdayakan masyarakat miskin.

Selain itu, tindakan pemberdayaan oleh pihak gereja dan pemerintah dalam ikatan kerja sama juga dapat dilakukan dengan menggunakan pendekatan appreciative inquiry. Artinya bahwa pendekatan ini cenderung mengutamakan dorongan dari masyarakat miskin secara personal dengan melihat berbagai kelebihan yang dapat dijadikan sebagai sumber pemberdayaan. Dalam hal ini, gereja dan pemerintah terutama harus menjadikan masyarakat miskin sebagai subjek pemberdayaan. Setelah itu, kedua pihak dapat melakukan empat langkah dasar dari pendekatan appreciative inquiry, yakni discovery, dream, design, dan destiny.

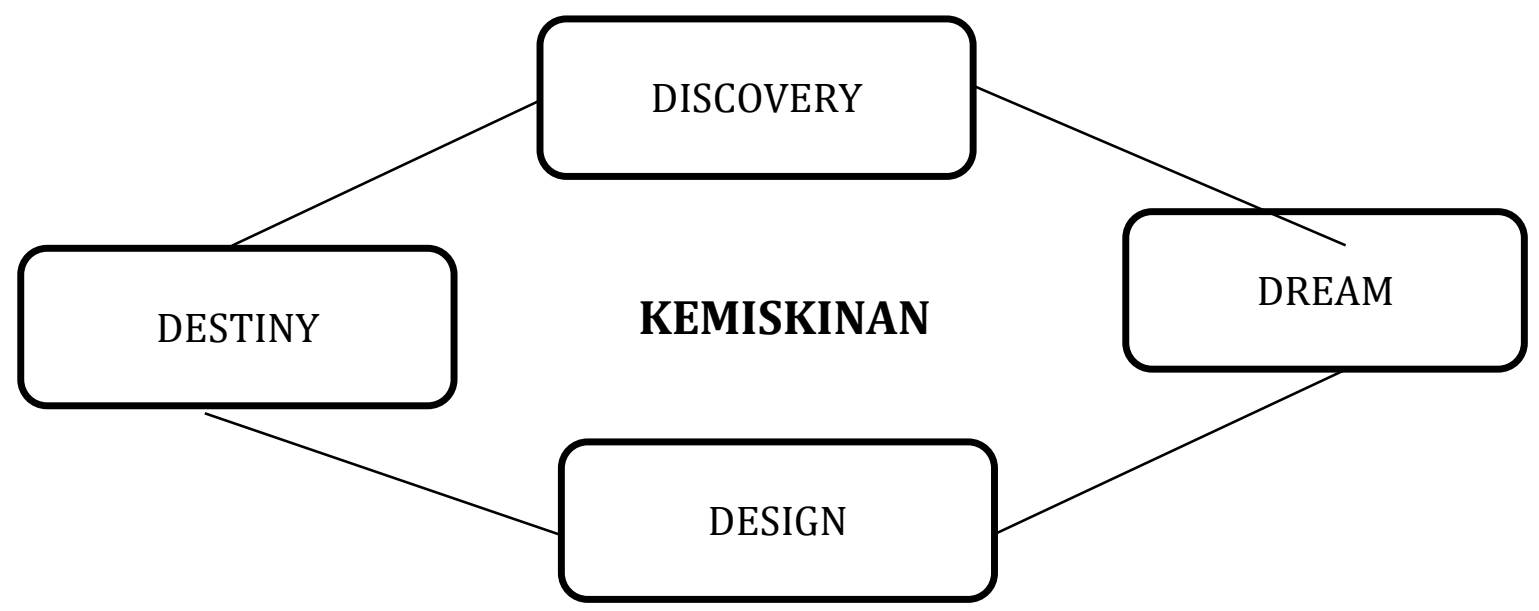

Bagan 2. Pemberdayaan menggunakan Pendekatan Appreciative Inquiry.

${ }^{28}$ Ajaran Gereja Protestan Maluku Nomor 130 tentang Hubungan Gereja dan Negara. 
Pertama, discovery. Pada langkah ini, gereja dan pemerintah mengidentifikasi masalah kemiskinan melalui apresiasi hal-hal positif yang dapat menjadi kekuatan dari masalah tersebut. Kedua, dream. Gereja dan pemerintah berimajinasi tentang masyarakat yang ideal di masa depan. Dalam hal ini, informasi yang ditemukan pada tahap sebelumnya dijadikan sebagai pijakan untuk menemukan kemungkinan masa depan masyarakat. Ketiga, design. Gereja dan pemerintah menciptakan atau mendesain program yang dapat mendukung secara kolaboratif. Keempat, destiny. Gereja dan pemerintah menguatkan kapasitas dukungan terhadap keseluruhan masyarakat untuk membangun harapan, menciptakan sesuatu yang baru, menyesuaikan dan berimprovisasi. Langkah ini memberdayakan mereka untuk mencapai visi masa depan masyarakat yang mengalami perubahan. Dengan demikian, tindakan pemberdayaan yang dilakukan oleh gereja dan pemerintah tidak hanya menggunakan kekuatan dari luar masyarakat miskin, tetapi justru mendorong mereka dari dalam untuk saling memanusiakan dengan kekuatan yang dimiliki.

\section{Kesimpulan}

Masalah kemiskinan yang dihadapi oleh masyarakat dusun Siahari mencakup berbagai aspek kehidupan, yakni pendidikan, kesehatan, ekonomi dan infrastruktur yang meliputi transportasi, perumahan dan air minum.Hal ini disebabkan oleh tingkat sumber daya manusia yang rendah, kelalaian pemerintah terhadap masyarakat-masyarakat yang terpencil dan kesadaran untuk mengembangkan diri secara maksimal.Dengan kata lain, masyarakat dusun Siahari mengalami kemiskinan secara absolut sebab pendapatan masyarakat tidak cukup untuk memenuhi kebutuhan hidup minimum; kemiskinan relatif yang terjadi karena ada kebijakan pembangunan yang belum menjangkau seluruh masyarakat; dan juga kemiskinan struktural yang terjadi karena keberpihakan pemerintah terkait pembangunan hanya terjadi di wilayah-wilayah transmigrasi. Masalah kemiskinan yang dihadapi oleh umat Siahari mengindikasikan bahwa gereja terpanggil untuk membebaskan umat dari penderitaan yang dihadapi. Dalam hal ini, gereja dapat melakukan tindakan pemberdayaan yang bersifat kontinu dengan berlandas pada ajaranajaran Yesus Kristus di dalamnya termasuk spiritualitas ugahari. Selain itu, gereja juga dapat membangun kerja sama dengan pemerintah dan menjadikan masyarakat miskin sebagai subjek pemberdayaan. Hal ini dilakukan agar tindakan pemberdayaan bagi masyarakat miskin dapat menciptakan transformasi secara holistik dan komprehensif. 


\section{Referensi}

Abineno, J. L. Ch. Apa Kata Alkitab? I. Jakarta: BPK Gunung Mulia, 1981.

Brownlee, Malcolm. Tugas Manusia Dalam Dunia Milik Tuhan. Jakarta: BPK Gunung Mulia, 2011.

Chen, Martin.Teologi Gustavo Gutierrez: Refleksi dari Praksis Kaum Miskin. Yogyakarta: Kanisius, 2002.

Hehanussa, Josef. "Pelayanan Diakonia yang Transformatif: Tinjauan Kritis terhadap Pelaksanaan Diakonia Gereja” Jurnal Gema 36. No. 1 (2012), 127-138.

Kirk, J. Andrew. Apa itu Misi? Suatu Penelusuran Teologis. Jakarta: BPK Gunung Mulia, 2012.

Moleong, Lexy J. Metodologi Penelitian Kualitatif. Bandung: Remaja Rosdakaria, 1998.

Nanuru, Richardo. "Gereja di Jalan Keadilan: Fungsi Sosial Gereja Menghadapi Masalah Kemiskinan dan Ketumpangan Komunikasi di Bibir Pasifik," OSF Home (Oktober 2017).

Nugroho, Fibry Jati. "Gereja dan Kemiskinan: Diskursus Peran Gereja di tengah Kemiskinan," EVANGELIKAL: Jurnal Teologi dan Pembinaan Warga Jemaat, 3. No. 1 (2019): 100-112.

Osmer, Richard R. Practical Theology: An Introduction (Michigan: Grand Rapids, 2008), dalam Panduan Penulisan Tesis Program Pasca Sarjana Teologi UKIM.

PGI.Dokumen Keesaan Gereja: Persekutuan Gereja-gereja di Indonesia 2014-2019.Jakarta: BPK Gunung Mulia, 2015. Potret dan Tantangan Gerakan Oikumene.Jakarta: BPK Gunung Mulia, 2015.

Singgih, Emanuel Gerrit. Berteologi dalam Konteks. Yogyakarta: Kanisius, 2000.

Siswanto, Krido. "Tinjauan Teoritis dan Teologis terhadap Diakonia Transformatif Gereja", Jurnal Simpson 1. No. 1 (2014), 95-120.

Sugiyono, Metode Penelitian Kuantitatif, Kualitatif dan R\&D. Bandung: Alfabeta, 2013.

Suharto, Edi.Membangun Masyarakat Memberdayakan Rakyat: Kajian Strategis Kesejahteran Sosial dan Pekerjaan Sosial.Bandung: Refika Aditama, 2006.

Widyatmadja, Josef P. Yesus dan Wong Cilik: Praksis Diakonia Transformatif dan Teologi Rakyat di Indonesia. Jakarta: BPK Gunung Mulia, 2010. 